\title{
Production of free-gluten bread from some cereal crops
}

\author{
M. A. Rizk ${ }^{1}$, N. I. Darwish ${ }^{1}$, H. M. Yousef ${ }^{1,}{ }^{*}$, E. A. Abd EL Rahim ${ }^{2}$ and I. A. El Saied ${ }^{3}$ \\ ${ }^{1}$ Department of Biochemistry, Faculty of Agriculture, Al-Azhar University, Cairo, Egypt \\ ${ }^{2}$ Food Technology Research Institute, Agriculture Research Center, Giza, Egypt \\ ${ }^{3}$ Grand Cairo Bakeries Company, Giza, Egypt \\ *Correspondence: hanyyousef@azhar.edu.eg (H. Yousef)
}

\begin{abstract}
Bread is an important source of nutrition around the world. But there are a large number of people have gluten sensitivity which found in wheat and barley, so the manufacture of bread from free- gluten cereal is essential for these people. This study concerned with the production of free- gluten flat bread using corn and rice, in addition to a new crop that has recently cultivated in Egypt, which is the quinoa crop due to its high nutritional value and free of gluten. Flat bread was produced using mixture of $100 \%$ extraction rate of quinoa, $100 \%$ extraction rate of white rice flour and $97 \%$ extraction rate of yellow corn flour. Blends were prepared by adding them in different proportions. Physicochemical properties were studied using chemically analyzed for both row materials and different blends. The sensory evaluation and the staling were conducted to the flat bread in order to determine the best blend. By studying the sensory evaluation and the staling, it became clear that the blends of quinoa flour supplemented by white rice flour is the best. On the other hand, the increasing of the ratio of the yellow corn in the blends leads to decreasing the freshmen of the flat bread. While, the existence of the white rice flour in the blends decreases the effect of the yellow corn flour.
\end{abstract}

Keywords: Flat bread; Quinoa flour; White rice flour; Yellow corn flour.

\section{INTRODUCTION}

Celiac disease (CD) is an immune-mediated enteropathy triggered by the ingestion of certain cereals, including wheat, rye, barley, triticale and oats in genetically susceptible persons (Bascuñán et al., 2017 and Leonard et al., 2017). To develop gluten-free (GF) breads for celiac patients, a number of alternative flour types, such as corn, rice, cassava, soybean, chickpea, teff and pseudocereals (e.g. quinoa, buckwheat and amaranth) have been evaluated to substitute wheat flour (Capriles and Areas, 2014; Martínez and Gomez, 2017; Sarabhai et al., 2017 and Romero et al., 2018 a).

Quinoa flour is used as a food for patients suffering from celiac disease, where quinoa flour is mixed with white rice flour and yellow corn flour to increase nutritional value (Pico et al., 2017 and Romano et al., 2018 b).

Different flour types have been investigated for developing free- gluten of flat bread.

Quinoa, which follows the Chenopodium quinoa Willd family, is a source of protein, mineral salts and vitamins. It is also free of gluten and therefore is considered as the suitable diet for celiac disease patients, which provides them with beneficial nutrients (Föste et al., 2014 and Peñas et al., 2014).

Rice is the seed of the grass species Oryza sativa (Asian rice) or Oryza glaberrima (African rice). As a cereal grain, it is the most widely consumed staple food for a large part of the world's human population, especially in Asia (Torres et al., 2014).

The corn is followed Zea mays L., and it is the essential item for the production of bread. Corn has become a staple food in many parts of the world, with total production surpassing that of wheat or rice (Brites et al., 2010).

The objectives of this study are to compare the influence of replacing 20\%,40\%,60\% and $80 \%$ of quinoa flour with white rice flour and yellow corn on the textural characteristics of the flat bread, freshly baked and stored for 3 days, and to assess the sensory characteristics of the fresh flat bread.

\section{MATERIALS AND METHODS}

\section{Characterization}

Commercial types of quinoa flour (100\% extraction), white rice flour (100\% extraction) and yellow corn flour (97\% extraction) were milled to obtain different blends using hummer laboratory mill as presented in Table (1).

\section{Preparation of Flat Bread}

Different blends were used to prepare the flat bread, with the addition of yeast and low sugar, to activate the yeast function, with the use of boiling water temperature of $100^{\circ} \mathrm{C}$ (traditional method). The bread was formed and flattened manually. The dough left to ferment for 30 minutes and then bread. The following blends, which include the raw materials (quinoa flour, white rice flour and yellow corn flour) are used. 
Table 1. The percentage of different experimental flour blends.

\begin{tabular}{cccc}
\hline Blends & quinoa flour $\%$ & white rice flour $\%$ & yellow corn flour $\%$ \\
\hline 1 & 100 & - & - \\
2 & - & 100 & - \\
3 & - & - & 100 \\
4 & 80 & 20 & - \\
5 & 60 & 40 & - \\
6 & 40 & 60 & - \\
7 & 20 & 80 & - \\
8 & 80 & - & 20 \\
9 & 60 & - & 40 \\
10 & 40 & - & 60 \\
11 & 20 & - & 80 \\
12 & - & 60 & 40 \\
13 & - & 40 & 60 \\
14 & - & 20 & 80 \\
15 & - & 10 & 10 \\
16 & 80 & 20 & 20 \\
17 & 60 & 30 & 30 \\
18 & 40 & 40 & 40 \\
19 & 20 & & \\
\hline
\end{tabular}

\section{Chemical Analysis}

Raw materials and blends were chemically analyzed using eleven properties. Some of the properties are related to the basic components of the grain, namely: Moisture, Protein Content, Total Fat, Total Carbohydrate, Fiber and Ash Content. The other is concerned with minerals elements, namely: Calcium (Ca), Iron (Fe), Zinc $(\mathrm{Zn})$, Sodium $(\mathrm{Na})$, Potassium $(\mathrm{K})$. According to method described by A.O.A.C. (2005).

\section{Preparation of Flat Bread}

Flat bread was prepared using the gelatinization method.

In traditional method, $(100 \mathrm{~g})$ of flour from any raw materials or blends were mixed with $(0.5 \mathrm{~g})$ salt, $(1 \mathrm{~g})$ yeast and $(1 \mathrm{~g})$ sugar. Then added 80 $\mathrm{mL}$ boiled water at degree up to $100{ }^{\circ} \mathrm{C}$, to form dough which was divided into $(50 \mathrm{~g})$ portions 20 $\mathrm{Cm}$ diameter shaping and left to ferment for 30 minutes. The dough was baked in oven at $350{ }^{\circ} \mathrm{C}$ for two min, then ventilated the bread, packed in polyethylene bags and stored at $4^{\circ} \mathrm{C}$ until analyses. This coincides with the results of (Choi and Kerr, 2004).

\section{Evaluation of Flat Bread}

To evaluate the resulting bread, the sensory evaluation and the staling were done to the flat bread.

\section{Sensory Evaluation of Flat Bread}

Flat bread was evaluated for Loaf rising, Crust Quality, Crust color, Crumb color, Odor, Taste and Crumb uniformity. The quality scoring was conducted by using a maximum of twenty a committee of experienced panelists from food technology research institute (FTRI) to evaluate organolyptically the different characteristics of flat bread. Score of each parameter as reported by Twillman and white (1988).

\section{Staling Evaluation of Flat Bread}

The staling of flat bread at different storage times $0,12,24,36$ and $72 \mathrm{~h}$ at room temperature, was tested by alkaline water retention capacity (AWRC) determination according to the method of Kitterman and Rubenthaler 1971. The loaves were dried in air oven at $35-40{ }^{\circ} \mathrm{C}$, milled in hummer mill and passed through wire sieves with 30 mish. five grams of dried flat bread was placed into a dry plastic centrifuge tube of $50 \mathrm{~mL}$ capacity then, $25 \mathrm{~mL}$ of $\mathrm{NaHCO}_{3}$ solution $(8.4 \mathrm{~g}$ sodium bicarbonate dissolved in one litter distilled water) was added. The tube was stoppered and shacked until all flat bread flour was wetted, the mixture left for $20 \mathrm{~min}$ with shacking every 5 minutes. The contents were centrifuged at 2500 r.p.m. for $15 \mathrm{~min}$, the supernatant was decanted and the precipitate was left for $10 \mathrm{~min}$ at 45 angles (to get rid of free water). The alkaline water retention capacity (A W R C) are given using the equation:

A W R C $=($ Weight of Precipitated of bread loves - weight of bread loaves) X 100

\section{Statistical Analysis}

All the data are analyzed using SPSS v 20.

The two ways analysis of variance (ANOVA) (Blocked Design) is used to analyses the data. The null hypothesis $\left(\mathrm{H}_{0}\right)$ is that all the means are equal (there is no significant differences between the treatments), and the alternative hypothesis $\left(\mathrm{H}_{1}\right)$ is that all the means are not equal (there we a significant difference between the treatments). We accept the null hypothesis when the $p$-value for the interaction F-test is greater than $0.005(P>$ $0.05)$, and reject the null hypothesis when the $p$ value for the interaction F-test is less than 0.005 $(P<0.05)$. (Kleinbaum et al., 1998 and Snedecor and Cochran, 1980. 
To show the relationship between the staling and its factors, a regression equation was gotten (Graybill et al., 1994).

\section{RESULTS AND DISCUSSION}

\section{Physicochemical Properties}

The physicochemical analysis for the used materials and different blends are shown in Table (2).

It is noticed that, the protein content found with the highest value in the quinoa flour (14.4) and the lowest value in the white rice flour (6), while the yellow corn flour contains (6.6).

To explain the result of the ash content, it must be looked into the data of the total fiber, since there is a positive relation between them. It is found that the quinoa flour has the greatest amount of the fiber (6.8), followed by the yellow corn flour (3.3) and the white rice flour has the lowest rate (2.4). Due to the bran layers has the highest mineral content.

Table 2. Physicochemical properties of $100 \%$ extraction rate of quinoa flour, $100 \%$ extraction rate of white rice flour and $97 \%$ extraction rate of yellow corn flour and different blends.

\begin{tabular}{|c|c|c|c|c|c|c|c|c|c|c|c|}
\hline The Materials & Moisture & $\begin{array}{l}\text { Protein } \\
\text { Content }\end{array}$ & Total Fat & $\begin{array}{c}\text { Total } \\
\text { Carbohydrate }\end{array}$ & Fiber & $\begin{array}{c}\text { Ash } \\
\text { Content }\end{array}$ & $\mathrm{Ca}$ & $\mathrm{Fe}$ & $\mathrm{Zn}$ & $\mathrm{Na}$ & $\mathrm{K}$ \\
\hline Quinoa flour & 13.6 & 14.4 & 6.0 & 64.2 & 6.8 & 2.2 & 52.0 & 4.1 & 3.0 & 8.0 & 540 \\
\hline White rice flour & 12.1 & 6.0 & 1.2 & 80.0 & 2.4 & 0.6 & 14.0 & 0.5 & 0.6 & 4.0 & 86 \\
\hline Yellow corn flour & 11.4 & 6.6 & 2.9 & 79.0 & 3.3 & 0.6 & 6.0 & 1.0 & 0.6 & 3.0 & 128 \\
\hline $\mathrm{Q} 80+\mathrm{R} 20$ & 13.3 & 12.8 & 5.1 & 66.8 & 5.8 & 1.8 & 45.0 & 3.3 & 2.5 & 7.0 & 440 \\
\hline $\mathrm{Q} 60+\mathrm{R} 40$ & 13.1 & 11.1 & 4.0 & 70.5 & 5.1 & 1.5 & 35.0 & 2.7 & 2.1 & 6.5 & 350 \\
\hline $\mathrm{Q} 40+\mathrm{R} 60$ & 12.9 & 9.3 & 3.2 & 73.6 & 4.0 & 1.2 & 30.0 & 1.8 & 1.7 & 5.0 & 270 \\
\hline Q $20+R 80$ & 12.4 & 7.7 & 2.3 & 76.6 & 3.4 & 1.0 & 20.0 & 1.2 & 1.1 & 4.0 & 180 \\
\hline $\mathrm{Q} 80+\mathrm{C} 20$ & 13.2 & 12.7 & 5.2 & 67.0 & 6.0 & 1.8 & 41.0 & 3.4 & 2.5 & 7.0 & 455 \\
\hline $\mathrm{Q} 60+\mathrm{C} 40$ & 12.5 & 11.4 & 4.9 & 69.8 & 5.3 & 1.7 & 33.0 & 2.9 & 2.0 & 6.0 & 370 \\
\hline $\mathrm{Q} 40+\mathrm{C} 60$ & 12.1 & 9.6 & 4.2 & 72.2 & 4.8 & 1.3 & 25.0 & 2.1 & 1.7 & 5.0 & 290 \\
\hline Q $20+C 80$ & 11.8 & 8.0 & 3.4 & 76.3 & 3.9 & 1.0 & 15.0 & 1.7 & 1.0 & 4.0 & 210 \\
\hline $\mathrm{R} 80+\mathrm{C} 20$ & 12.1 & 6.0 & 1.4 & 79.8 & 2.6 & 0.55 & 13.0 & 0.6 & 0.6 & 4.0 & 95 \\
\hline R $60+C 40$ & 11.8 & 6.1 & 1.8 & 79.7 & 2.8 & 0.57 & 11.0 & 0.7 & 0.6 & 4.0 & 105 \\
\hline R $40+C 60$ & 11.8 & 6.4 & 2.2 & 79.5 & 2.9 & 0.59 & 9.0 & 0.8 & 0.6 & 4.0 & 115 \\
\hline R $20+C 80$ & 11.4 & 6.5 & 2.5 & 79.2 & 3.0 & 0.60 & 8.0 & 0.9 & 0.6 & 4.0 & 122 \\
\hline $\mathrm{Q} 80$ + R 10 + C10 & 13.4 & 12.8 & 5.1 & 67.5 & 6.0 & 1.88 & 45.0 & 3.4 & 2.4 & 7.0 & 450 \\
\hline $\mathrm{Q} 60+\mathrm{R} 20$ + C20 & 13.0 & 11.3 & 4.5 & 70.3 & 5.3 & 1.50 & 35.0 & 2.7 & 2.0 & 6.0 & 370 \\
\hline $\mathrm{Q} 40+\mathrm{R} 30+\mathrm{C} 30$ & 12.6 & 9.6 & 3.6 & 73.0 & 4.5 & 1.25 & 27.0 & 2.0 & 1.6 & 5.0 & 280 \\
\hline $\mathrm{Q} 20+\mathrm{R} 40+\mathrm{C} 40$ & 8.0 & 5.5 & 2.5 & 76.6 & 2.7 & 0.72 & 13.0 & 1.2 & 0.9 & 3.0 & 160 \\
\hline
\end{tabular}

Source: prepared by the researcher based on the results of the experiments.

\section{Sensory Evaluation}

The objective of sensory evaluation method is to measure the human response to product characteristics that can be perceived by the sense evaluation. Seven characteristics of sensory evaluation were evaluated by twenty panelists. The seven characteristic are: Loaf rising, Crust Quality,
Crust color, Crumb color, Odor, Taste and Crumb uniformity. Results of sensory evaluation of flat bread prepared with quinoa flour 100\% extraction rate blended with yellow corn flour 97 $\%$ and white rice flour $100 \%$ extraction rate are shown in Table (3). 
Table 3. Sensory Evaluation of flat bread prepared from quinoa flour $100 \%$ extraction rate blended with yellow corn flour $97 \%$ and white rice flour $100 \%$ extraction rate.

\begin{tabular}{|c|c|c|c|c|c|c|c|c|}
\hline Blends & Loaf rising & $\begin{array}{c}\text { Crust } \\
\text { Quality }\end{array}$ & $\begin{array}{l}\text { Crust } \\
\text { color }\end{array}$ & $\begin{array}{r}\text { Crumb } \\
\text { color }\end{array}$ & $\begin{array}{c}\text { Crumb } \\
\text { uniformity }\end{array}$ & Odor & Taste & $\begin{array}{l}\text { Total } \\
\text { Scores }\end{array}$ \\
\hline Score & 10 & 10 & 15 & 15 & 10 & 20 & 20 & 100 \\
\hline Quinoa flour & 5 & 5 & 5.5 & 5.5 & 5 & 13 & 13 & 52.0 \\
\hline $\begin{array}{l}\text { White rice flowir } \\
\text { Yellow corn flour }\end{array}$ & $\frac{8.5}{5}$ & $\begin{array}{c}8.5 \\
5\end{array}$ & $\begin{array}{c}13.5 \\
6\end{array}$ & $\begin{array}{c}13.5 \\
6\end{array}$ & $\begin{array}{l}8 \\
5\end{array}$ & $\begin{array}{l}19 \\
19\end{array}$ & $\begin{array}{l}14 \\
14\end{array}$ & $\begin{array}{l}90 \\
55\end{array}$ \\
\hline Q $80+R 20$ & 7 & 7.5 & 11.5 & 12 & 7.5 & 18 & 18.5 & 82 \\
\hline $\mathrm{Q} 60+\mathrm{R} 40$ & 7 & 7.5 & 11.5 & 11.5 & 7.5 & 18 & 18 & 81 \\
\hline $\mathrm{Q} 40+\mathrm{R} 60$ & 7 & 7 & 11 & 11 & 7.5 & 18 & 18 & 79.5 \\
\hline Q $20+R 80$ & 7 & 7 & 10.5 & 10.5 & 7 & 17.5 & 17.5 & 76.5 \\
\hline$Q 80+C 20$ & 5 & 5 & 6.5 & 6.5 & 5.5 & 15 & 15 & 58.5 \\
\hline Q $60+C 40$ & 5.5 & 5.5 & 7 & 7 & 6 & 15.5 & 15.5 & 62 \\
\hline Q $40+C 60$ & 6 & 6 & 8 & 8 & 6 & 16 & 16 & 66 \\
\hline Q $20+C 80$ & 6 & 6 & 8.5 & 8.5 & 6 & 16.5 & 16 & 67.5 \\
\hline R $80+C 20$ & 8 & 8 & 13 & 13 & 8 & 18 & 18 & 86 \\
\hline R $60+C 40$ & 7.5 & 8 & 12 & 12.5 & 8 & 18 & 18 & 84 \\
\hline $\begin{array}{l}\text { R } 40+C 60 \\
\text { R } 20+C 80\end{array}$ & $\begin{array}{l}7 \\
7\end{array}$ & $\begin{array}{c}7.5 \\
7\end{array}$ & $\begin{array}{c}12 \\
10.5\end{array}$ & $\begin{array}{c}12 \\
10.5\end{array}$ & $\begin{array}{c}8 \\
7.5\end{array}$ & $\begin{array}{c}18 \\
17.5\end{array}$ & $\begin{array}{c}18.5 \\
18\end{array}$ & $\begin{array}{l}83 \\
78\end{array}$ \\
\hline Q80 + R 10 + & 6 & 6 & 9 & 9 & 7 & 17 & 16 & 70 \\
\hline Q60 + R 20 + & 6 & 6.0 & 9 & 9 & 7 & 17 & 16.5 & 71 \\
\hline $\mathrm{Q} 40+\mathrm{R} 30+$ & 6.5 & 7 & 10 & 10 & 7 & 17.5 & 17 & 75 \\
\hline $\mathrm{Q} 20+\mathrm{R} 40+\mathrm{C} 40$ & 7 & 7 & 9 & 9 & 7.5 & 18 & 18 & 75.5 \\
\hline
\end{tabular}

From the statistical analyzed for the three raw materials (the quinoa flour, the white rice flour and the yellow corn flour), it is found that all the characteristics have significant differences $(P<$ 0.05). while, when using the multiple comparisons, it is found that there is similarity in all characteristics $(P>0.05)$ (except the crumb uniformity) between the quinoa flour and the corn flour. This similarity may be due to the composition of rice starch differs from maize and quinoa starch in terms of percentage of amylose and amylopectin.

When adding the white rice flour by ratio $80 \%$ to quinoa flour, it decreased the values of sensory to the flat bread made from this blend compared with the $20 \%, 40 \%$ and $60 \%$. This decline may be due to the different in chemical composition between the white rice flour and quinoa flour. From the statistical analysis for the four different levels of the quinoa flour supplemented by white rice flour, it can be noticed that all characteristics have no significant differences $(P>0.05)$ except the crumb color $(P<0.05)$. While using the quinoa flour as control, it is found that all characteristics have significant differences $(P<0.05)$. When using the white rice flour as control, the crumb uniformity and taste only have no significant differences $(P>0.05)$. These results are consistent with Patil and Arya (2018).

Concerning to the yellow corn blends group, values indicated that when increasing the ratio of yellow corn in blends, we observe an increase in the values of all characteristics. It may be due to the chemical composition is somewhat similar between both quinoa and yellow corn, which improves the quality of the resulting bread. When comparing statistically the results of the four blends (without control) it was found that each increase in the ratio of yellow corn in the blends leads to differences between the groups except crust quality, crumb uniformity and taste. Taking quinoa or corn as a control, it is found that there is a difference in all characteristics except crust quality. This shows that the differences occur in groups with high corn ratio, these results are in agreement with those reported by $\mathrm{Al}$ Shehry (2016).

Adding the white rice flour by $80 \%, 60 \%, 40 \%$ and $20 \%$ to yellow corn flour, decreased the values of the sensory. This may be due to the difference in the chemical structure between white rice flour and yellow corn flour. When comparing the blends without any control, there is no significant differences in crust quality, odder and taste only. Also using white rice as control there is no significant differences in crust quality and taste. While yellow corn flour and quinoa flour are used as control, it is found that all characteristics have significant differences. These findings are consistent with Ávila et al. (2017). 
In the blends which containing the three raw materials, we note that increasing the ratio of white rice flour and yellow corn flour lead to increasing in the values of the sensory properties. This is may be due to the effect of the white rice flour is better than the effect of the yellow corn flour. When comparing statistically the blends which contains the three types of flour with quinoa flour as control. It is noticed that all characteristics have significant differences $(P<$ $0.05)$. When comparing the blends without any control, there is no significant differences in crust quality, crumb uniformity, odor and taste. While using white rice flour and yellow corn flour as control all characteristics have significant differences except crumb uniformity.

Generally, starch grains (granules) in quinoa flour are small in comparison to starch grains (granules) in both white rice flour and yellow corn flour, which means that they carry a wide range of temperatures for the process of crystallization. Therefore, the high percentage of quinoa flour in the mixture may give good characteristics to the resulting bread

\section{Staling Evaluation}

From Table (4), it is noticed that the staling for flat bread prepared from white rice flour has the maximum values, followed by the quinoa flour. While the values of that prepared with yellow corn flour are the minimum. This is may be due to that the rate of amylose and amylopectin in the white rice starch are varying than their rate in the quinoa flour and yellow corn flour, this result agrees with Seyhun et al. (2005) and Sidhu et al. (1997). These reasons may be lead to that the flat bread is more refresh than which made from corn flour.

When comparing the different blends, it is found that the values of stalling are improved by increasing the ratio of white rice in the blends.

This means that the greater the proportion of rice flour in the produced bread, the more it will be freshness in other blends.

The regression equation is

$$
y=368.725+0.29 Q+0.23 R-0.041 C-1.697
$$

hours.

Where: $\mathrm{y}$ is the staling values (the dependent variable). The independents variables are: $Q$ : the proportion of quinoa flour. R: the proportion of white rice flour. C: the proportion of yellow corn flour. hours: time of staling .

Table 4. Staling of flat bread prepared with $100 \%$ extraction rate of quinoa flour, $100 \%$ extraction rate of white rice flour and $97 \%$ extraction rate of yellow corn flour and different blends.

\begin{tabular}{|c|c|c|c|c|c|c|c|c|c|}
\hline \multirow{2}{*}{ The Materials } & \multicolumn{9}{|c|}{ Hours } \\
\hline & $\begin{array}{l}\text { Zero } \\
\text { time }\end{array}$ & $12 \mathrm{~h}$ & $\begin{array}{c}\text { Decreasing } \\
\text { Rate } \%\end{array}$ & $24 \mathrm{~h}$ & $\begin{array}{c}\text { Decreasing. } \\
\text { Rate } \%\end{array}$ & $36 \mathrm{~h}$ & $\begin{array}{c}\text { Decreasing } \\
\text { Rate } \%\end{array}$ & $72 \mathrm{~h}$ & $\begin{array}{c}\text { Decreasing } \\
\text { Rate } \%\end{array}$ \\
\hline Quinoa flour & 382 & 362 & 5.24 & 333 & 12.83 & 299 & 24.92 & 252 & 43.48 \\
\hline White rice flour & 381 & 373 & 2.10 & 354 & 7.09 & 334 & 13.28 & 318 & 18.86 \\
\hline Yellow corn flour & 380 & 358 & 5.79 & 328 & 13.68 & 287 & 28.35 & 248 & 45.99 \\
\hline Q $80+$ R 20 & 380 & 363 & 4.47 & 337 & 11.26 & 280 & 26.32 & 255 & 32.89 \\
\hline $\mathrm{Q} 60+\mathrm{R} 40$ & 383 & 366 & 4.33 & 341 & 10.86 & 286 & 25.33 & 262 & 31.59 \\
\hline $\mathrm{Q} 40+\mathrm{R} 60$ & 381 & 369 & 3.25 & 346 & 9.29 & 292 & 23.36 & 270 & 29.13 \\
\hline Q $20+R 80$ & 382 & 371 & 2.93 & 350 & 8.43 & 298 & 21.99 & 276 & 27.75 \\
\hline $\mathrm{Q} 80+\mathrm{C} 20$ & 382 & 358 & 6.28 & 330 & 13.61 & 280 & 26.70 & 266 & 30.37 \\
\hline Q $60+C 40$ & 383 & 360 & 6.01 & 331 & 13.58 & 281 & 26.63 & 270 & 29.50 \\
\hline $\mathrm{Q} 40+\mathrm{C} 60$ & 380 & 358 & 5.79 & 330 & 13.16 & 283 & 25.53 & 275 & 27.63 \\
\hline Q $20+C 80$ & 381 & 360 & 5.62 & 332 & 12.86 & 285 & 25.20 & 279 & 26.77 \\
\hline $\mathrm{R} 80+\mathrm{C} 20$ & 380 & 366 & 3.68 & 349 & 8.21 & 308 & 18.95 & 285 & 25.00 \\
\hline $\mathrm{R} 60+\mathrm{C} 40$ & 382 & 366 & 4.19 & 344 & 9.95 & 302 & 20.94 & 281 & 26.44 \\
\hline $\mathrm{R} 40+\mathrm{C} 60$ & 383 & 364 & 4.96 & 344 & 10.29 & 300 & 21.67 & 273 & 28.72 \\
\hline R $20+C 80$ & 380 & 360 & 5.26 & 340 & 10.53 & 294 & 22.63 & 266 & 30.00 \\
\hline $\mathrm{Q} 80+\mathrm{R} 10+\mathrm{C} 10$ & 380 & 358 & 5.79 & 335 & 11.95 & 297 & 21.84 & 220 & 42.11 \\
\hline $\mathrm{Q} 60+\mathrm{R} 20+\mathrm{C} 20$ & 381 & 360 & 5.51 & 336 & 11.76 & 299 & 21.52 & 230 & 39.63 \\
\hline $\mathrm{Q} 40+\mathrm{R} 30+\mathrm{C} 30$ & 381 & 361 & 5.25 & 338 & 11.34 & 301 & 21.00 & 238 & 37.53 \\
\hline $\mathrm{Q} 20+\mathrm{R} 40+\mathrm{C} 40$ & 380 & 361 & 5.00 & 339 & 10.68 & 308 & 18.95 & 246 & 35.26 \\
\hline
\end{tabular}

Source: prepared by the researcher based on the results of the experiments. 


\section{REFERENCES}

Al Shehry, G.A., 2017. Use of corn and quinoa flour to produce bakery products for celiac disease. Adv. Environ. Biol. 10 (12), 237-2 44.

A.O.A.C., 2005. Official Methods of Analysis of the Association of Official Analytical Chemists. 18th Edition, Association of Official Analytical Chemists. Arlington, Virginia.

Ávila, B., Braganca, G., Rockenbach, R., Alves, G., Monks, J., Gularte, M., Elias, M., 2017. Physical and sensory characteristics of cake prepared with six whole-grain flours. J. Food Meas. Charact. 11(3), 1486-1492.

Bascuñán, K., Vespa, M., Araya, M., 2017. Celiac disease. understanding the gluten-free diet. Eur. J. Nutr. 56 (2), 449-459.

Brites, C., Trigo, M.J., Santos, C., Concha, C., 2010. MaizeBased gluten-free bread: influence of processing parameters on sensory and instrumental quality. Food Bioprocess Technol. 3 (5), 707-715.

Capriles, V.D., Areas, J., 2014. Novel approaches in glutenfree bread making: interface between food science, nutrition, and health. Compr. Rev. Food Sci. Food Saf. 13 (5), 871-890.

Choi, S.G., Kerr, W.L., 2004. Swelling characteristics of native and chemically modified wheat starches as a function of heating temperature and time. Starch. 56 (5), 181189.

Föste, M., Nordlohne, S.D., Elgeti, D., Linden, M.H., Heinz, V., Jekle, M., Becker, T., 2014. Impact of quinoa bran on gluten-free dough and bread characteristics. Eur. Food Res. Technol. 239 (5), 767-775

Graybill, F.A., Mood, A.M., Boes, D.C., 1994. Introduction to the Theory of Statistics, 3rd Edition, McGraw-Hill Publishing Company, NY.

Kitterman, J.S., Rubenthaler, G.L., 1971. Assessing the quality of early generation wheat selection with the micro ARWRC test. Cereal Sci. Today. 16 (8), 313-318.

Kleinbaum, D.G., Kupper, L.L. Muller, K.E., 1998. Applied Regression Analysis and Other Multivariable Methods, 2nd Edition, Boston, MA.

Leonard, M.M., Sapone, A., Catassi, C., Fasano, A., 2017. Celiac disease and nonceliac gluten sensitivity: a review. JAMA. 318 (7), 647-656.
Martínez, M.M., Gomez, M., 2017. Rheological and microstructural evolution of the most common gluten-free flours and starches during bread fermentation and baking. J. Food Eng. 197, 78-86.

Patil, S., Arya, S., 2018. Optimization and characterization of gluten-free formulation for the development of gluten free flatbread using underutilised sources. Curr. Res. Nutr. Food Sci. 6 (3), 678-689.

Peñas, E., Uberti, F., di Lorenzo, C., Ballabio, C., Brandolini, A., Restani, P., 2014. Biochemical and immunochemical evidences supporting the inclusion of quinoa (Chenopodium quinoa Willd.) as a gluten-free ingredient. Plant Foods Hum. Nutr. 69, 297-303.

Pico, J., Bernal, J., Gomez, M., 2017. Influence of different flours and starches on gluten-free bread aroma. J. Food Sci. Technol. 54 (6), 1433-1441.

Romero, M.C., Fogar, R.A., Rolhaiser, F., Clavero, V., Romero A.M., Judis, M.A., 2018 a. Development of gluten-free fish (Pseudoplatystoma corruscans) patties by response surface methodology. J. Food Sci. Technol. 55 (5), 1889-1902.

Romano, M.C., Masi, P., Bracciale, A., Aiello, A., Nicolai, M.A. Ferranti, P., 2018 b. Effect of added enzymes and quinoa flour on dough characteristics and sensory quality of a gluten-free bakery product. Eur. Food Res Technol. 244 (9), 1595-1604.

Sarabhai, S., Sudha, M.L., Prabhasankar, P., 2017. Rheological characterization and biscuit making potential of gluten free flours. J. Food Meas. Charact. 11, 14491461.

Seyhun, N., Sumnu, G., Sahin , S., 2005. Effects of different starch types on retardation of staling of microwavebaked cakes. Food Bioprod. Process. 83 (1), 1-5.

Sidhu, J.S., Al-Saqer, J., Al-Zenki, S., 1997. Comparison of methods for the assessment of the extent of staling in bread. Food Chem. 58 (1-2), 161-167.

Snedecor, G.W., Cochran, W.G., 1980. Statistical Methods. $7^{\text {th }}$ Edition, Iowa State University Press, Ames, Iowa.

Torres, M.D., Fradinho, P., Raymundo, A., Sousa, I., 2014. Thermorheological and textural behaviour of glutenfree gels obtained from chestnut and rice flours. Food Bioprocess Technol. 7 (4), 1171-1182.

Twillman, T.J., White, P.J., 1988. Influence of monoglycerides on the texture, shelf life and dough reheology of corn tortillas. Cereal Chem. 65 (3), 253-57. 


\section{دراسات على بعض محاصيل الحبوب لانتاج المبز المالي من الجلوتين}

\section{محمد على رذق '، ناير ابراهيم حسن درويش '، هاني يوسف محمد يوسف '، عيد احمد محمد عبد الرحيم ؟، اسلام احمد جلال الدين السيد '

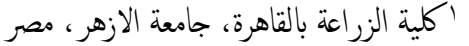

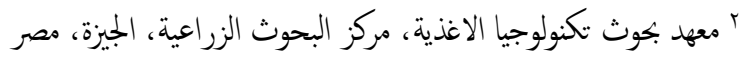

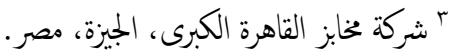

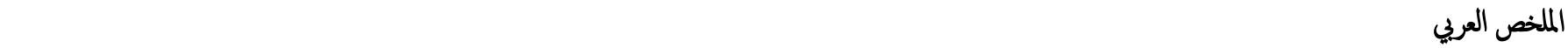

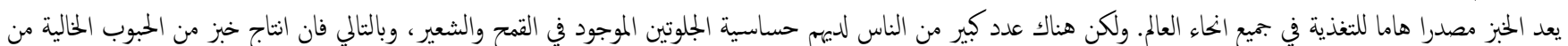

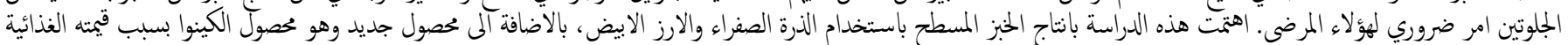

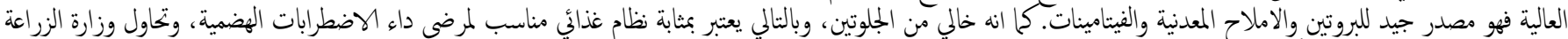

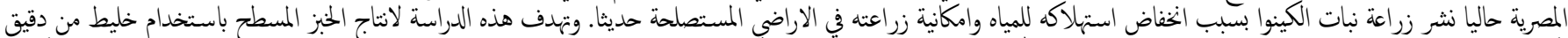

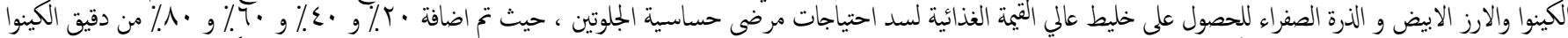

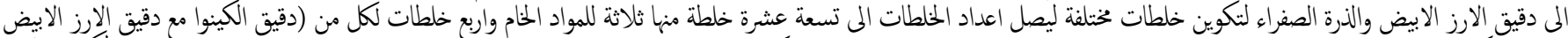

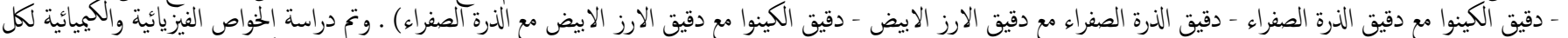

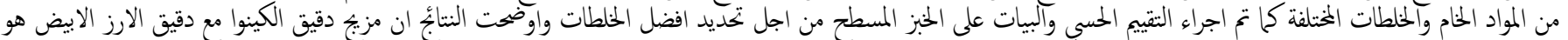

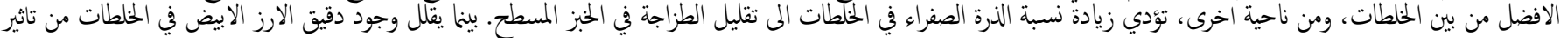
دقيق الذزة الاصفر. 